\title{
On effect of rhenium on mechanical properties of a high-Cr creep- resistant steel
}

\author{
A. Fedoseeva*, I. Nikitin, N. Dudova, R. Kaibyshev \\ Belgorod National Research University, Belgorod 308015, Russia
}

\section{A R T I C L E I N F O}

Article history:

Received 10 September 2018

Received in revised form 10 October 2018

Accepted 13 October 2018

Available online 15 October 2018

\section{Keywords:}

Metals and alloys

Creep

Electron Microscopy

Microstructure

Particles

Diffusion

\begin{abstract}
A B S T R A C T
9-12\% Cr martensitic steels are perspective materials for critical components of new high-efficiency power plants working at ultra-supercritical parameters of steam. Addition of $0.2 \%$ rhenium in the experimental steel improved the short-term creep strength at $650{ }^{\circ} \mathrm{C}$. Comparison of kinetics of tungsten depletion from the matrix in different high-Cr martensitic steels showed that rhenium in the experimental $10 \mathrm{Cr}-3 \mathrm{Co}-3 \mathrm{~W}-0.2 \mathrm{Re}$ steel did not lead to retaining an increased amount of solute $\mathrm{W}$ in the ferritic matrix during both aging and creep at $650{ }^{\circ} \mathrm{C}$. At the same time, the precipitation of the high fraction of the fine Laves phase particles provided the effective particle strengthening.
\end{abstract}

(c) 2018 Elsevier B.V. All rights reserved.

\section{Introduction}

The heat-resistant steels with $9-12 \% \mathrm{Cr}$ like a TOS series are used for critical components of boilers, steam main pipes and turbines of fossil fuel power plants with increased thermal efficiency [1-7]. TOS203 steel was developed by Toshiba in 1980's for hightemperature blade [2,4-6] which had the increased $W$ and decreased Mo contents and an addition of Re, comparing with the TOS202 and TOS110 rotor steels [2]. Rhenium has been suggested an effective contributor to creep strength of nickel-base superalloys [8]. In the TOS203 steel, rhenium acts as a solid solution strengthener and maintains an increased amount of solute tungsten in the matrix during creep or thermal aging at 600 and $650{ }^{\circ} \mathrm{C}[2,4-6,9]$. Moreover, Re significantly suppresses the $\mathrm{W}$ diffusion in Fe-15 mol.\%Cr-based alloy [10].

It is worth noting that experimental data on the Re effect on creep behavior were obtained during creep at $550-650{ }^{\circ} \mathrm{C}$ for high-chromium martensitic steels with standard $\mathrm{N}$ content (0.03-0.05 wt\%), high Ni content (about $0.6 \mathrm{wt} \%$ ) and low Co content (about $1 \mathrm{wt} \%$ ) [2,4-6,9]. However, the recent investigations of alloy design [11-15] showed that modification of the TOS110 steel by reducing nitrogen and increasing boron demonstrated an improved creep resistance up to $40,000 \mathrm{~h}$ at $650{ }^{\circ} \mathrm{C} / 120 \mathrm{MPa}$. Rhenium addition to this modification of the TOS110 steel may further

\footnotetext{
* Corresponding author.

E-mail address: fedoseeva@bsu.edu.ru (A. Fedoseeva).
}

improve the creep strength. The aim of the present work is to report the positive effect of rhenium on the creep strength of $10 \mathrm{wt} \% \mathrm{Cr}-3 \% \mathrm{Co}-3 \% \mathrm{~W}$ martensitic steel containing $0.002 \% \mathrm{~N}$ and $0.008 \% \mathrm{~B}$ during creep and aging at $650{ }^{\circ} \mathrm{C}$.

\section{Material and experimental}

$100 \mathrm{~kg}$ steel ingot containing rhenium, denoted here as $10 \mathrm{Cr}-$ $3 \mathrm{Co}-3 \mathrm{~W}-0.2 \mathrm{Re}$, was prepared by vacuum induction melting. The steel was normalized at $1050^{\circ} \mathrm{C}$ for $1 \mathrm{~h}$, air quenched and tempered at $770{ }^{\circ} \mathrm{C}$ for $3 \mathrm{~h}$. The Re-free $9 \mathrm{Cr}-3 \mathrm{Co}-3 \mathrm{~W}-0 \mathrm{Re}$ steel $[16,17]$, Re-free $10 \mathrm{Cr}-3 \mathrm{Co}-2 \mathrm{~W}-0$ Re steel with high $\mathrm{B}$ and low $\mathrm{N}$ contents (modified TOS110 steel) [12-15] and TOS203 steel containing $0.2 \% \operatorname{Re}[2-6]$ were used for comparison to clarify the rhenium effect on the mechanical properties and microstructural changes. The chemical compositions and heat treatments of the steels are listed in Table 1.

Tensile tests were carried out on the specimens having a cross section of $1.5 \times 3 \mathrm{~mm}^{2}$ and a $16 \mathrm{~mm}$ gauge length using an Instron 5882 testing machine at temperatures of $20,500,600$ and $650{ }^{\circ} \mathrm{C}$ with a strain rate of $2 \times 10^{-3} \mathrm{~s}^{-1}$. Flat specimens with a gauge length of $25 \mathrm{~mm}$ and a cross section of $7 \times 3 \mathrm{~mm}^{2}$ were subjected to creep tests until rupture at $650{ }^{\circ} \mathrm{C}$ under initial stresses ranging from 100 to $200 \mathrm{MPa}$. The structural characterization of ruptured crept specimens was carried out using a JEM-2100 transmission electron microscope (TEM). Phase analysis of the precipitated particles extracted from the steel samples by electrolysis was carried 
Table 1

Chemical compositions of the steels studied (in wt\%) and their heat treatments.

\begin{tabular}{|c|c|c|c|c|c|c|c|c|c|c|c|}
\hline & $\mathrm{C}$ & $\mathrm{Cr}$ & Co & Mo & W & V & $\mathrm{Nb}$ & B & $\mathrm{N}$ & $\mathrm{Ni}$ & $\operatorname{Re}$ \\
\hline $10 \mathrm{Cr}-3 \mathrm{Co}-3 \mathrm{~W}-0.2 \mathrm{Re}$ & 0.11 & 9.85 & 3.2 & 0.13 & 3.2 & 0.2 & 0.07 & 0.008 & 0.002 & 0.03 & 0.17 \\
\hline $9 \mathrm{Cr}-3 \mathrm{Co}-3 \mathrm{~W}-0 \mathrm{Re}[16,17]$ & 0.12 & 9.5 & 3.2 & 0.45 & 3.1 & 0.2 & 0.06 & 0.005 & 0.05 & 0.2 & - \\
\hline Mod. TOS110 [12-15] & 0.10 & 10.0 & 3.0 & 0.70 & 2.0 & 0.2 & 0.05 & 0.008 & 0.003 & 0.17 & - \\
\hline TOS203 [2-6] & 0.11 & 10.5 & 1.0 & 0.1 & 2.5 & 0.2 & 0.1 & 0.01 & 0.03 & 0.6 & 0.2 \\
\hline
\end{tabular}

$10 \mathrm{Cr}-3 \mathrm{Co}-3 \mathrm{~W}-0.2 \mathrm{Re}$ : Normalized at $1050{ }^{\circ} \mathrm{C}$ for $1 \mathrm{~h}$, air quenched and tempered at $770{ }^{\circ} \mathrm{C}$ for $3 \mathrm{~h}$.

$9 \mathrm{Cr}-3 \mathrm{Co}-3 \mathrm{~W}-0 \mathrm{Re}[16,17]$ : Normalized at $1050^{\circ} \mathrm{C}$ for $0.5 \mathrm{~h}$, air quenched and tempered at $750{ }^{\circ} \mathrm{C}$ for $3 \mathrm{~h}$.

Mod. TOS110 [12-15]: Normalized at $1060^{\circ} \mathrm{C}$ for $0.5 \mathrm{~h}$, air quenched and tempered at $770{ }^{\circ} \mathrm{C}$ for $3 \mathrm{~h}$.

TOS203 [5]: Normalized at $1120^{\circ} \mathrm{C}$ for $3 \mathrm{~h}$, oil quenched and tempered at $680^{\circ} \mathrm{C}$ for $5 \mathrm{~h}$.

out by X-ray diffraction (XRD) using a Rigaku Ultima IV diffractometer.

\section{Results and discussion}

An average size of prior austenite grains (PAGs) in the $10 \mathrm{Cr}$ 3Co-3W-0.2Re steel was $55 \mu \mathrm{m}$ after final heat treatment. An average lath thickness was approximately $0.3 \mu \mathrm{m}$. The high dislocation density of approximately $2 \times 10^{14} \mathrm{~m}^{-2}$ was observed within the lath interiors. The fine $\mathrm{M}_{23} \mathrm{C}_{6}$ carbides with a mean size of $70 \mathrm{~nm}$ were located on the boundaries of PAGs/packets/blocks/laths, and the NbX carbonitrides with a mean size of $40 \mathrm{~nm}$ were uniformly distributed within the martensitic laths.

Ultimate tensile strength (UTS) (Fig. 1a) and yield strength (YS) (Fig. 1b) of the $10 \mathrm{Cr}-3 \mathrm{Co}-3 \mathrm{~W}-0.2 \mathrm{Re}$ steel continuously decrease as testing temperature increases. UTS and YS of the $10 \mathrm{Cr}-3 \mathrm{Co}-3 \mathrm{~W}-$ 0.2Re steel correspond to those for the Re-free 9Cr-3Co-3W-0Re [16] and modified TOS110 [12,14] steels, whereas UTS of the TOS203 steel [5] is higher at all testing temperatures and YS is higher only at ambient temperature. Remarkably higher UTS and YS values of the TOS203 steel as compared to other steels are attributed to lower tempering temperature (Table 1). Thus, rhenium in the $10 \mathrm{Cr}-3 \mathrm{Co}-3 \mathrm{~W}-0.2 \mathrm{Re}$ steel does not affect an overall strengthening at temperatures of 20,600 and $650{ }^{\circ} \mathrm{C}$ (Fig. $1 \mathrm{a}$ and b).

Fig. 1c shows the creep rupture data for the steels at $650{ }^{\circ} \mathrm{C}$. At short-term creep tests with rupture time $<5000 \mathrm{~h}$, the $9 \mathrm{Cr}-3 \mathrm{Co}$ 3 W-ORe [16,17] and TOS 203 [5] steels had the significant advantage, whereas appearance of creep strength breakdown dramatically reduced their creep resistance at long-term creep. Both steels showed the same creep strength after 10,000 h due to the high nitrogen content. On the other hand, the modified TOS110 steel with lower $\mathrm{N}$ content demonstrated an improved creep strength during long-term creep up to $40,000 \mathrm{~h}$ [15]. The $0.2 \%$ Re addition and increase in $\mathrm{W}$ content up to $3 \%$ in the experimental $10 \mathrm{Cr}-3 \mathrm{Co}-3 \mathrm{~W}$ $0.2 \mathrm{Re}$ steel led to significant increase in the short-term creep strength in comparison with the modified TOS110 steel. Longterm creep tests of the $10 \mathrm{Cr}-3 \mathrm{Co}-3 \mathrm{~W}-0.2 \mathrm{Re}$ steel are in progress.

For all steels, the $\mathrm{W}$ content in the matrix reaches values of 1.3 and $1.2 \mathrm{wt} \%$ after $\sim 1000 \mathrm{~h}$ of thermal aging or $\sim 500 \mathrm{~h}$ of creep at $650^{\circ} \mathrm{C}$, respectively (Fig. 2). Creep accelerates the tungsten depletion from the matrix. Depletion of tungsten, $f(W)$, is independent of steel alloying and could be described as

$f(W) \sim 2.17 \exp (-0.0033 t)$ during aging

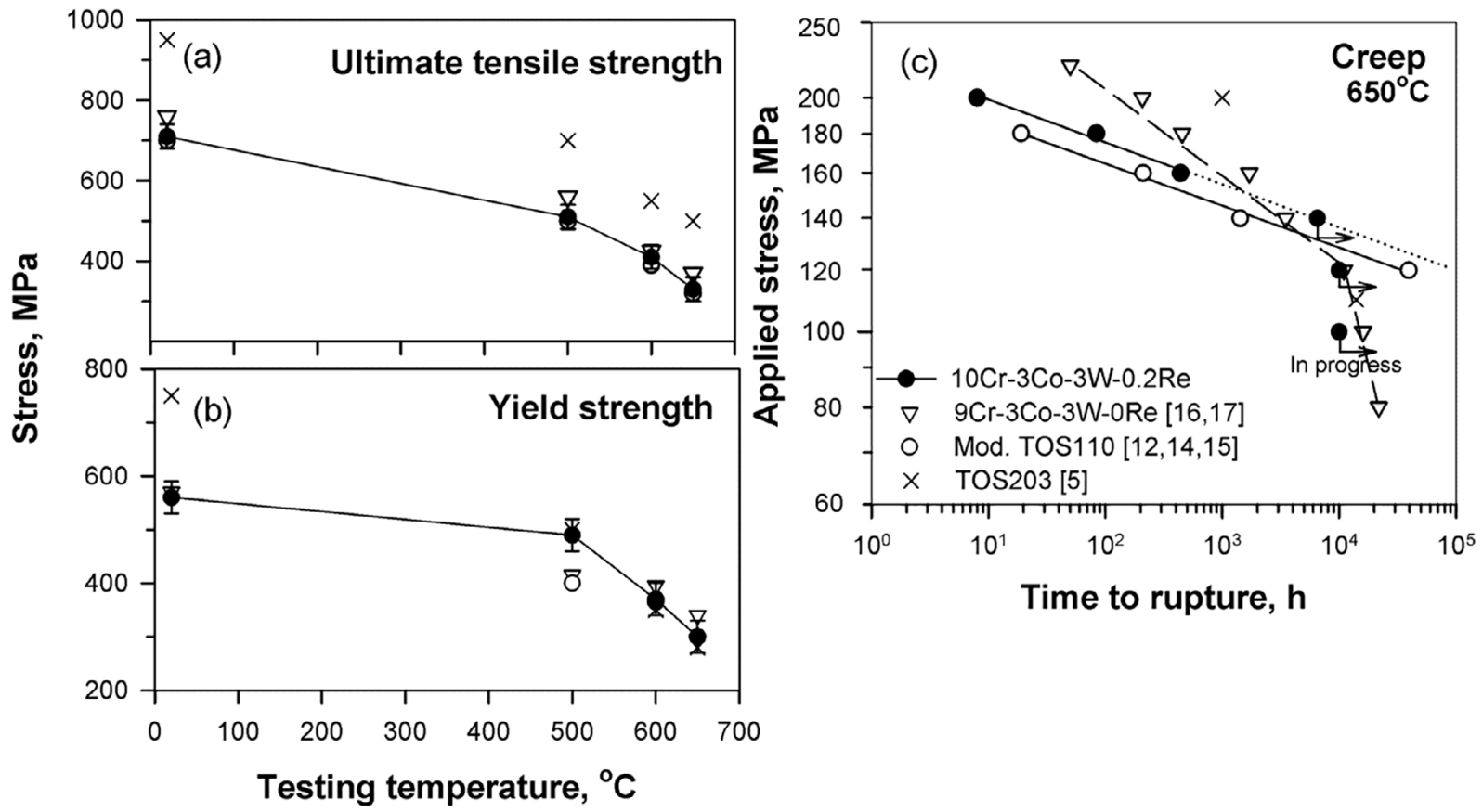

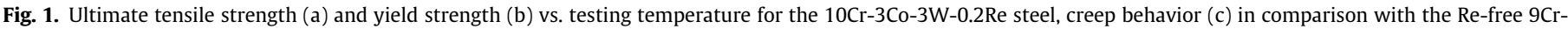
3 Co-3 W-0Re [16,17], modified TOS110 [12,14,15] and TOS203 [5] steels. 

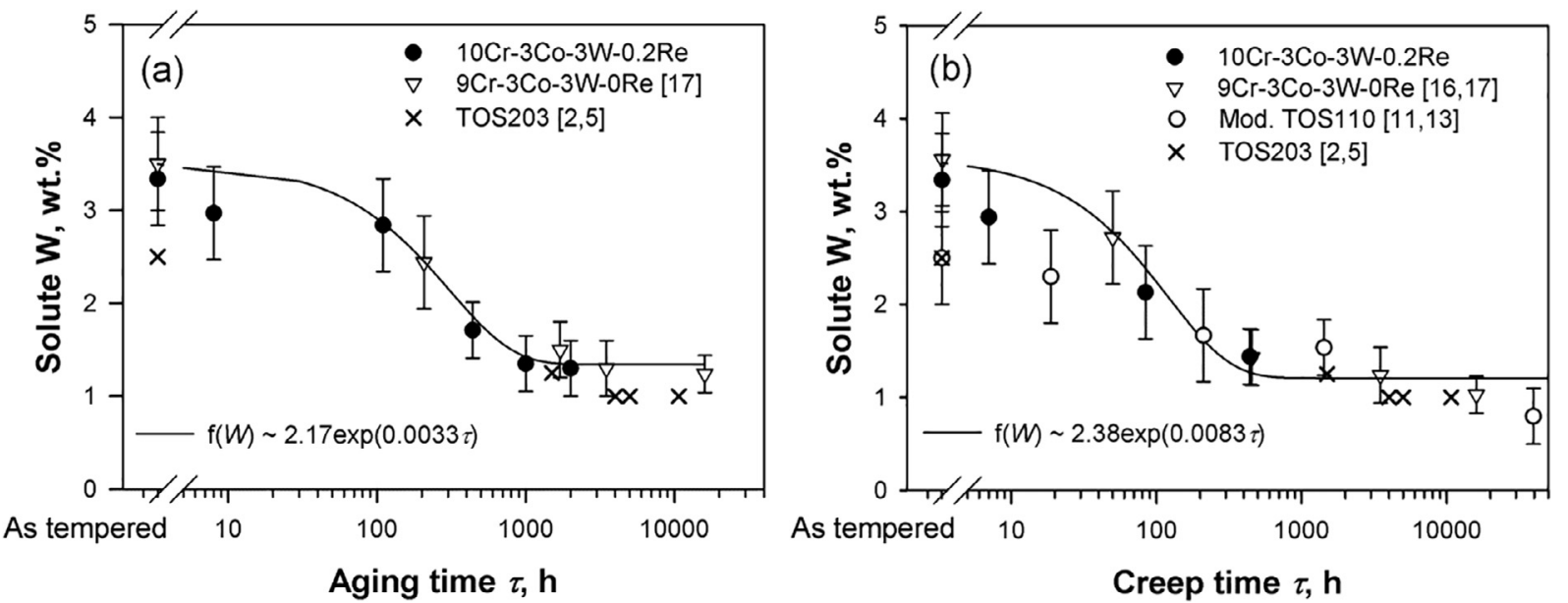

Fig. 2. Change in the tungsten content in the ferritic matrix during aging (a) and creep (b) at $650{ }^{\circ} \mathrm{C}$.

\section{$f(W) \sim 2.38 \exp (-0.0083 t)$ during creep}

Rhenium in the $10 \mathrm{Cr}-3 \mathrm{Co}-3 \mathrm{~W}-0.2 \mathrm{Re}$ and TOS203 steels did not lead to retaining an increased amount of solute $\mathrm{W}$ in the ferritic matrix during both thermal aging and short-term creep at $650^{\circ} \mathrm{C}$ that contradicts data represented in [2,4-6]. These relations (1-2) were obtained in the previous investigations [16]. Initially higher $\mathrm{W}$ content in the $10 \mathrm{Cr}-3 \mathrm{Co}-3 \mathrm{~W}-0.2 \mathrm{Re}$ and $9 \mathrm{Cr}-3 \mathrm{Co}-3 \mathrm{~W}-0 \mathrm{Re}$ steels provides an increment in the solid solution strengthening only during the first $100 \mathrm{~h}$ of creep/aging at $650^{\circ} \mathrm{C}$ before the precipitation of Laves phase, $\mathrm{Fe}_{2}(\mathrm{~W}, \mathrm{Mo})$. The Laves phase particles precipitate along the boundaries of PAGs/laths in the $10 \mathrm{Cr}-3 \mathrm{Co}-3 \mathrm{~W}$ 0.2 Re steel during the first $100 \mathrm{~h}$ of creep/aging at $650{ }^{\circ} \mathrm{C}$ (Fig. 3). The volume fraction of the Laves phase particles increases with increasing the creep/aging time, wherein the average size of these particles increases up to $100 \mathrm{~nm}$ after $2000 \mathrm{~h}$ of aging or $440 \mathrm{~h}$ of creep (Fig. 3b). In the $10 \mathrm{Cr}-3 \mathrm{Co}-3 \mathrm{~W}-0.2 \mathrm{Re}$ steel, the average size of the Laves phase particles was significantly less than that (152 $\mathrm{nm}$ after $278 \mathrm{~h}$ of creep) in the modified TOS110 steel [11] after short-term creep that is related to higher volume fraction of this phase $(1.88 \%$ in the $10 \mathrm{Cr}-3 \mathrm{Co}-3 \mathrm{~W}-0.2 \mathrm{Re}$ steel vs. $1.59 \%$ in the modified TOS110 steel according to Thermo-Calc prediction). The average sizes of $\mathrm{M}_{23} \mathrm{C}_{6}$ carbides and $\mathrm{NbX}$ carbonitrides remain about $70 \mathrm{~nm}$ and $40 \mathrm{~nm}$, respectively, during $2000 \mathrm{~h}$ of aging or $440 \mathrm{~h}$ of creep (Fig. 3b). In the modified TOS110 steel, the average sizes of these phases are $80 \mathrm{~nm}$ and $47 \mathrm{~nm}$, respectively, after $278 \mathrm{~h}$ of creep [11]. Therefore, rhenium retards the particle coarsening. Together the high volume fraction and the fine size of the Laves phase particles enhanced the stability of lath structure during creep that provided the increment in creep strength.

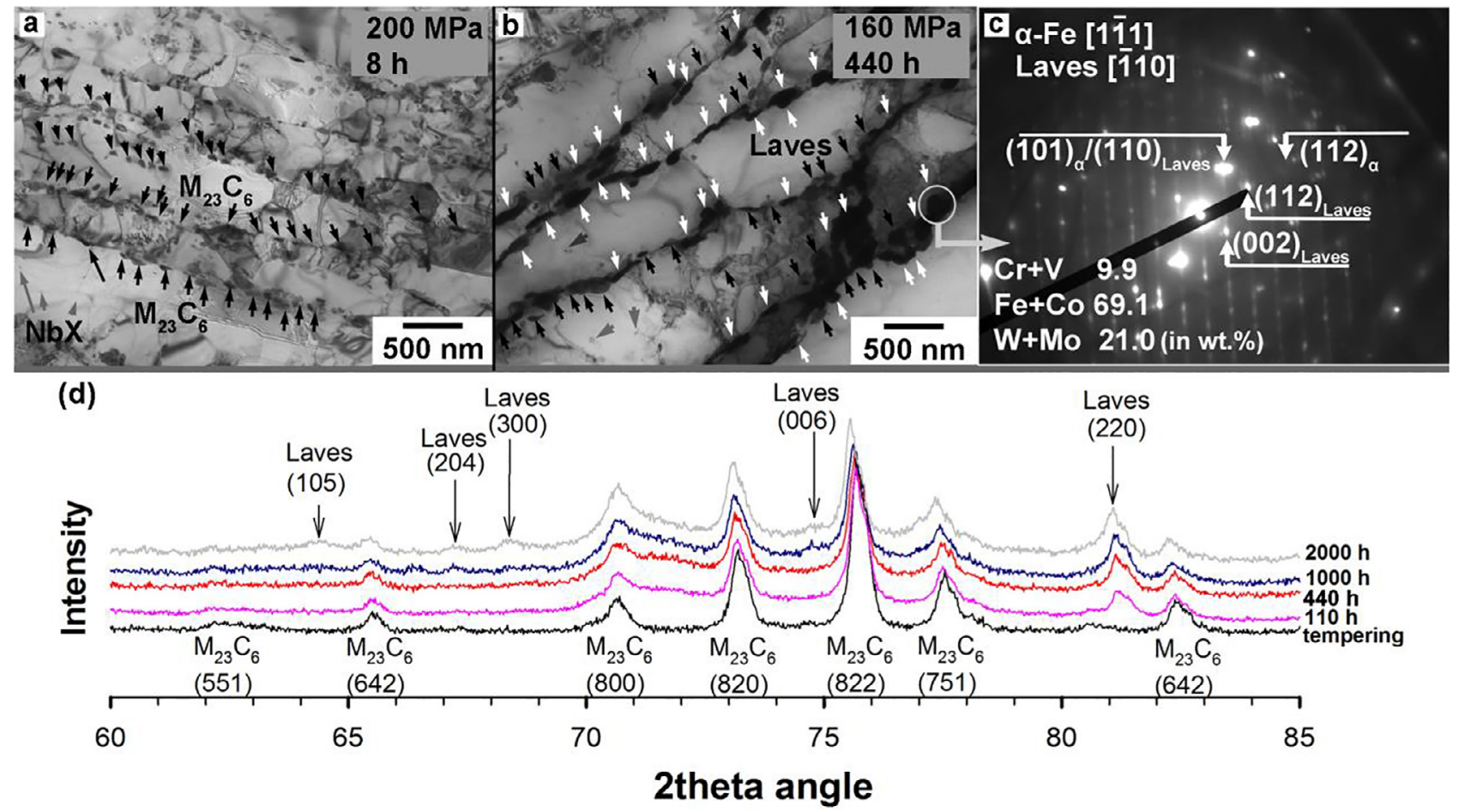

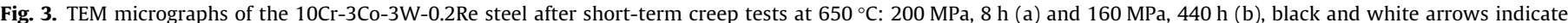

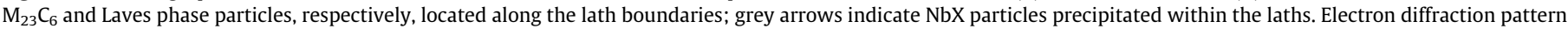

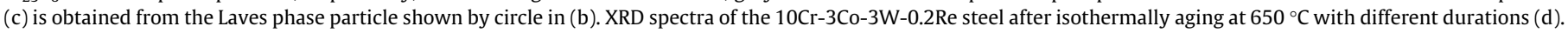




\section{Conclusions}

1) Addition of $0.2 \%$ rhenium in the experimental $10 \mathrm{Cr}-3 \mathrm{Co}-3 \mathrm{~W}$ 0.2Re steel improves its short-term creep strength, whereas it does not affect UTS and YS at testing temperatures of 20 , 600 and $650{ }^{\circ} \mathrm{C}$.

2) Addition of $0.2 \%$ rhenium did not lead to retaining an increased amount of solute tungsten in the ferritic matrix during both aging and creep at $650^{\circ} \mathrm{C}$. The increment in the creep strength in the experimental $10 \mathrm{Cr}-3 \mathrm{Co}-3 \mathrm{~W}-0.2 \mathrm{Re}$ steel is related to the precipitation of the high fraction of the fine Laves phase particles and retarding their coarsening.

\section{Acknowledgment}

This study was financially supported by the Russian Science Foundation, under grant No. 17-73-10380.

\section{References}

[1] F. Abe, T.U. Kern, R. Viswanathan, Creep Resistant Steels, Woodhead Publishing, Cambridge, England, 2008.
[2] M. Miyazaki, M. Yamada, Y. Tsuda, R. Ishii, Conf. Proc. Advanced heat resistant steels for power generation, 27-29 April 1998, San Sebastian, Spain, The Institute of Materials, London, 1999, pp. 574-585.

[3] R. Viswanathan, W. Bakker, J. Mat. Eng. Perform. 10 (2001) 96-101.

[4] M. Fukuda, Y. Tsuda, K. Yamashita, Y. Shinozaki, T. Takanashi, Conf. Proc. Advances in Materials Technology for Fossil Power Plants, 25-28 Oct. 2004, Hilton Head Island, South Carolina, ASM International, Materials Park, 2005, pp. 491-505.

[5] R. Ishii, Y. Tsuda, M. Yamada, Steel Forgings: Second Volume, ASTM STP 1259 ASTM International, West Conshohocken, 1997, pp. 317-329.

[6] T. Tanuma, Advances in Steam Turbines for Modern Power Plants, Woodhead Publishing, Cambridge, England, 2017.

[7] H.K.D.H. Bhadesha, ISIJ Int. 41 (2001) 626-640.

[8] G.W. Meetham, M.H. Van de Voorde, Materials for High Temperature Engineering Applications, Springer-Verlag, Berlin, 2012.

[9] R. Ishii, Y. Tsuda, M. Yamada, M. Miyazaki, Conf. Proc. Advanced heat resistant steels for power generation, 27-29 April, 1998 San Sebastian, Spain, The Institute of Materials, London, 1999, pp. 277-287.

[10] T. Kunieda, K. Yamashita, Y. Murata, T. Koyama, M. Morinaga, Mater. Trans. 47 (2006) 2106-2108.

[11] R. Mishnev, N. Dudova, A. Fedoseeva, R. Kaibyshev, Mater. Sci. Eng. A 678 (2016) 178-189.

[12] N. Dudova, R. Mishnev, R. Kaibyshev, ISIJ Int. 51 (2011) 1912-1918.

[13] R. Kaibyshev, R. Mishnev, A. Fedoseeva, N. Dudova, Mater. Sci. Forum 879 (2017) 36-41.

14] R. Mishnev, N. Dudova, R. Kaibyshev, J. Fatigue 83 (2016) 344-355.

[15] R. Mishnev, N. Dudova, R. Kaibyshev, Mater. Sci. Eng. A 713 (2018) 161-173.

[16] A. Fedoseeva, N. Dudova, R. Kaibyshev, A. Belyakov, Metals 7 (2017), Article No 573.

[17] A. Fedoseeva, N. Dudova, R. Kaibyshev, J. Mater. Sci. 52 (2017) 2974-2988. 